\title{
A PRELIMINARY OBSERVATION: MALE PATTERN HAIR LOSS AMONG HOSPITALIZED COVID-19 PATIENTS IN SPAIN - A POTENTIAL CLUE TO THE ROLE OF ANDROGENS IN COVID-19 SEVERITY
}

\author{
Goren A., ${ }^{1}$ Vano-Galvan S., ${ }^{2}$ Wambier C.G., ${ }^{3}$ McCoy J., ${ }^{1}$ Gomez-Zubiaur A., ${ }^{4}$ Moreno- \\ Arrones O.M., ${ }^{2}$ Shapiro J., ${ }^{5}$ Sinclair R., ${ }^{6}$ Gold M.H., ${ }^{7}$ Kovacevic M., ${ }^{8}$ Mesinkovska N.A., ${ }^{9}$ \\ Goldust M., ${ }^{10}$ Washenik K. ${ }^{5,11}$
}

1. Applied Biology, Inc., Irvine, CA, USA.

2. Dermatology Department, Ramon y Cajal Hospital, IRYCIS, University of Alcala, Madrid, Spain.

3. Department of Dermatology, The Warren Alpert Medical School of Brown University, RI, USA.

4. Department of Dermatology, Principe de Asturias Hospital, Alcala de Henares, Madrid, Spain.

5. Ronald O. Perelman Department of Dermatology at the New York University School of Medicine, NY, USA.

6. Sinclair Dermatology, Melbourne, VIC, Australia.

7. Gold Skin Care Center, Advanced Aesthetics Medical Spa, The Laser \& Rejuvenation Center, Nashville, TN, USA.

8. Department of Dermatology and Venereology, Clinical Hospital Center Sestre Milosrdnice Zagreb, Croatia.

9. Department of Dermatology. School of Medicine of the University of California Irvine, CA, USA.

10. Department of Dermatology, University Hospital Basel, Basel, Switzerland.

11. Bosley Medical Group, Beverly Hills, CA.

Corresponding author/reprint requests:

Carlos Gustavo Wambier, MD, PhD

Rhode Island Hospital - 593 Eddy Street, APC, $10^{\text {th }}$ Floor - Providence RI 02903

Email: carlos wambier@brown.edu

Funding sources: None

This is the author manuscript accepted for publication and has undergone full peer review but has not been through the copyediting, typesetting, pagination and proofreading process, which may lead to differences between this version and the Version of Record. Please cite this article as doi: 10.1111/JOCD.13443

This article is protected by copyright. All rights reserved 
Conflicts of interest: none declared.

Word count: 772

Figures: 0

References: 19

Keywords: COVID-19; SARS-CoV-2; androgen receptor; androgenetic alopecia; retinoids; anti-androgen therapy; Angiotensin Converting Enzyme 2; ACE2; human skin; transmembrane protease serine 2; TMPRSS2; Enzalutamide, Dutasteride; Finasteride; Cannabidiol; 5-alpha reductase;
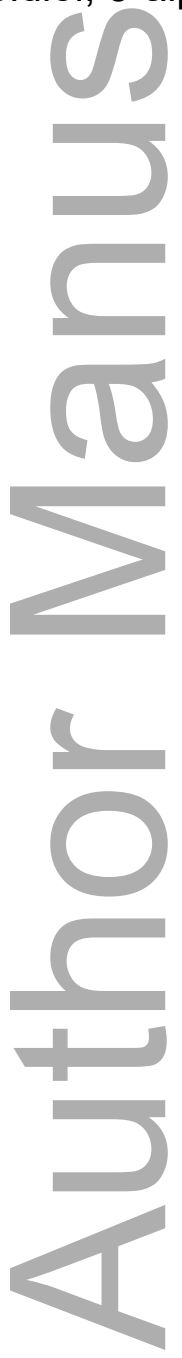

This article is protected by copyright. All rights reserved 
DR. CARLOS G WAMBIER (Orcid ID : 0000-0002-4636-4489)

DR. J. MCCOY (Orcid ID : 0000-0003-1577-9910)

DR. MICHAEL H. GOLD (Orcid ID : 0000-0002-5183-5433)

DR. MAJA KOVACEVIC (Orcid ID : 0000-0001-6579-5535)

Article type : Letter to the Editor

\section{A PRELIMINARY OBSERVATION: MALE PATTERN HAIR LOSS AMONG HOSPITALIZED COVID-19 PATIENTS IN SPAIN - A POTENTIAL CLUE TO THE ROLE OF ANDROGENS IN COVID-19 SEVERITY}

RUNNING TITLE:

MALE PATTERN HAIR LOSS IN HOSPITALIZED COVID19 PATIENTS

Keywords: COVID-19; SARS-CoV-2; androgen receptor; androgenetic alopecia; retinoids; anti-androgen therapy; Angiotensin Converting Enzyme 2; ACE2; human skin; transmembrane protease serine 2; TMPRSS2; Enzalutamide, Dutasteride; Finasteride; Cannabidiol; 5-alpha reductase;

\section{Abstract/summary:}

A preliminary observation of high frequency of male pattern hair loss among admitted COVID-19 patients, and suggest that androgen expression might be a clue to COVID19 severity.

During the continuing SARS-CoV-2 (COVID-19) pandemic, several studies have reported a significant difference in the rate of severe cases between adult females and adult males (42\% vs $58 \%) .{ }^{1}$ Among children under the age of 14 , the rate of severe cases was reported to be extremely low. ${ }^{1}$ To explain this difference, several theories have been proposed including cigarette smoking and lifestyle habits. However, no theory fits both the gender difference in 
severe cases as well as reduced risk in pre-pubescent children. Our past research on male androgenetic alopecia (AGA) has led us to investigate an association between androgens and COVID-19 pathogenesis. ${ }^{2}$ In normal subjects, androgen expression demonstrates significant variation between men and women as well as between adults and pre-pubescent children.

SARS-CoV-2 primarily infects type II pneumocytes in the human lung. SARS-CoV-2 enters pneumocytes, by anchoring to the ACE2 cell surface receptor. Prior to receptor binding, viral spike proteins undergo proteolytic priming by the transmembrane protease, serine 2 (TMPRSS2). ${ }^{3-5}$ TMPRSS2 inhibition or knock down reduces ability of SARS-CoV-1 (a related virus to SARS-CoV-2) to infect cells in vitro. ${ }^{6}$ Additionally, TMPRSS2 also facilitates entry of influenza $A$ and influenza $B$ into primary human airway cells and type II pneumocytes. ${ }^{7}$

The human TMPRSS2 gene has a $15 \mathrm{bp}$ androgen response element and in humans, androgens are the only known transcription promoters for the TMPRSS2 gene..$^{8-10}$ In a study of androgen-stimulated prostate cancer cells (LNCaP), TMPRSS2 mRNA expression increase was mediated by the androgen receptor. ${ }^{10}$ Further, the ACE2 receptor, also critical for SARS-CoV-2 viral infectivity, is affected by male sex hormones with higher activity found in males. ${ }^{11}$

Androgenetic alopecia (AGA), often referred to as male pattern hair loss, is the most common form of hair loss among men. ${ }^{12}$ The development of androgenetic alopecia is androgen mediated and is dependent on genetic variants found in the androgen receptor gene located on the $X$ chromosome. We hypothesized that males with AGA are more likely to be hospitalized for COVID-19 complications compared to controls. To explore this potential association, we conducted a preliminary observational study of the prevalence of AGA patients among hospitalized COVID-19 patients at two Spanish tertiary hospitals between March 23-April 6, 2020, the diagnosis of AGA was performed clinically by a dermatologist.

In total, 41 Caucasian males admitted to the hospitals with a diagnosis of bilateral SARS-CoV-2 pneumonia were analyzed. The mean age of patients was 58 years (range 23-79). Among them, 29 (71\%) were diagnosed with clinically significant AGA (Hamilton-Norwood scale higher than 2) and 12 (29\%) had clinically irrelevant relevant signs of AGA (Hamilton-Norwood scale 1 or 2). 16 (39\%), were classified as severe AGA (Hamilton-Norwood scale 4 to 7 ).

This article is protected by copyright. All rights reserved 
The precise prevalence of AGA among otherwise healthy Spanish Caucasian males is unknown; however, based on published literature, ${ }^{13,14}$ the expected prevalence of a similar agematched Caucasian population is approximately $31-53 \%$. Due to the burden exerted on the emergency departments participating in this study, the study was limited to visual diagnosis only; therefore, no information was available as to the use of anti-androgens, prostate cancer or benign prostatic hyperplasia; thus if a later study demonstrates that a significant portion of this population was already treated with androgen modulators it would alter the conclusion of this communication. Following this preliminary observation, we plan to conduct a controlled study to determine whether a correlation between androgens and COVID-19 disease severity exists.

If AGA is confirmed as a risk factor for increased severity of COVID-19 infection, then we could hypothesize that anti-androgen therapy may reduce the risk of developing severe symptoms following COVID-19 infection. While no anti-androgen therapy for COVID-19 has been studied to-date, recent attention to the anti-malarial drug hydroxychloroquine is of interest. Chloroquine phosphate, an analogue of hydroxychloroquine, has been demonstrated to reduce testosterone in rodents. ${ }^{15}$ Further, a combination of hydroxychloroquine and Itraconazole is being studied for the treatment of prostate cancer (NCT03513211). ${ }^{16}$ Although the data supporting the use of hydroxychloroquine for treatment of COVID-19 is limited and the potential negative side effects in COVID-19 patients are unknown, the connection to androgens may prove important. Finally, the US FDA has recently granted expanded emergency use access for nitric oxide as a treatment for COVID-19. The use of nitric oxide was demonstrated to inhibit androgen receptor activity in prostate cancer. ${ }^{17}$ If our theory proves correct, anti-androgen drugs could be employed, such as finasteride, dutasteride, spironolactone, enzalutamide, ${ }^{19}$ and possibly cannabidiol. 18

In conclusion, based on the scientific rationale combined with this preliminary observation, we believe investigating the potential association between androgens and COVID-19 disease severity warrants further merit. If such an association is confirmed, anti-androgens could be evaluated as a potential treatment for COVID-19 infection.

\section{REFERENCES}

1. Guan W-J, Ni Z-Y, Hu Y, et al. Clinical Characteristics of Coronavirus Disease 2019 in China. N Engl J Med. February 2020:NEJMoa2002032. doi:10.1056/NEJMoa2002032

This article is protected by copyright. All rights reserved 
2. Goren A, Mc Coy J, Wambier CG, et al. WHAT DOES ANDROGENETIC ALOPECIA HAVE TO DO WITH COVID-19? AN INSIGHT INTO A POTENTIAL NEW THERAPY. Dermatol Ther. April 2020:e13365. doi:10.1111/dth.13365

3. Shieh WJ, Hsiao CH, Paddock CD, et al. Immunohistochemical, in situ hybridization, and ultrastructural localization of SARS-associated coronavirus in lung of a fatal case of severe acute respiratory syndrome in Taiwan. Hum Pathol. 2005. doi:10.1016/j.humpath.2004.11.006

4. Hoffmann M, Kleine-Weber H, Schroeder S, et al. SARS-CoV-2 Cell Entry Depends on ACE2 and TMPRSS2 and Is Blocked by a Clinically Proven Protease Inhibitor. Cell. March 2020:1-10.

doi:10.1016/j.cell.2020.02.052

5. Glowacka I, Bertram S, Muller MA, et al. Evidence that TMPRSS2 Activates the Severe Acute Respiratory Syndrome Coronavirus Spike Protein for Membrane Fusion and Reduces Viral Control by the Humoral Immune Response. J Virol. 2011. doi:10.1128/jvi.02232-10

6. Heurich A, Hofmann-Winkler H, Gierer S, Liepold T, Jahn O, Pohlmann S. TMPRSS2 and ADAM17 Cleave ACE2 Differentially and Only Proteolysis by TMPRSS2 Augments Entry Driven by the Severe Acute Respiratory Syndrome Coronavirus Spike Protein. J Virol. 2014;88(2):1293-1307. doi:10.1128/JVI.02202-13

7. Limburg H, Harbig A, Bestle D, et al. TMPRSS2 Is the Major Activating Protease of Influenza A Virus in Primary Human Airway Cells and Influenza B Virus in Human Type II Pneumocytes. SchultzCherry S, ed. J Virol. 2019;93(21). doi:10.1128/JVI.00649-19

8. Lucas JM, Heinlein C, Kim T, et al. The Androgen-Regulated Protease TMPRSS2 Activates a Proteolytic Cascade Involving Components of the Tumor Microenvironment and Promotes Prostate Cancer Metastasis. Cancer Discov. 2014;4(11):1310-1325. doi:10.1158/2159-8290.CD-13-1010

9. National Institutes of Health. TMPRSS2 transmembrane serine protease 2 [ Homo sapiens (human) ] Gene ID: 7113. Gene ID: 7113, updated on 13-Mar-2020. https://www.ncbi.nlm.nih.gov/gene/7113. Published 2020. Accessed April 2, 2020.

10. Lin B, Ferguson C, White JT, et al. Prostate-localized and androgen-regulated expression of the membrane- bound serine protease TMPRSS2. Cancer Res. 1999.

11. Dalpiaz PLM, Lamas AZ, Caliman IF, et al. Sex Hormones Promote Opposite Effects on ACE and ACE2 Activity, Hypertrophy and Cardiac Contractility in Spontaneously Hypertensive Rats. Bader M, ed. PLoS One. 2015;10(5):e0127515. doi:10.1371/journal.pone.0127515

12. Gan DCC, Sinclair RD. Prevalence of male and female pattern hair loss in Maryborough. J Investig Dermatol Symp Proc. 2005;10(3):184-189. doi:10.1111/j.1087-0024.2005.10102.x 13. Severi G, Sinclair R, Hopper JL, English DR, McCredie MR, Boyle P, Giles GG. Androgenetic alopecia in men aged 40-69 years: prevalence and risk factors. Br J Dermatol. 2003; 149(6): 1207-1213. 14. Hamilton JB. Patterned loss of hair in man: Types and incidence. Ann N Y Acad Sci. 1951;53:708728.

This article is protected by copyright. All rights reserved 
15. Nicola WG, Khayria MI, Osfor MMH. Plasma testosterone level and the male genital system after chloroquine therapy. Boll Chim Farm. 1997.

16. Phase I/II Study of Hydroxychloroquine With Itraconazole With Biochemically Recurrent Prostate Cancer - Full Text View - ClinicalTrials.gov. https://clinicaltrials.gov/ct2/show/NCT03513211

17. Cronauer M V., Ince $\mathrm{Y}$, Engers $\mathrm{R}$, et al. Nitric oxide-mediated inhibition of androgen receptor activity: Possible implications for prostate cancer progression. Oncogene. 2007;26(13):1875-1884. doi:10.1038/sj.onc.1209984

18. Sharma, M. , Hudson, J., Adomat, H. , Guns, E. and Cox, M. (2014) In Vitro Anticancer Activity of Plant-Derived Cannabidiol on Prostate Cancer Cell Lines. Pharmacology \& Pharmacy, 5, 806-820. doi: $10.4236 /$ pp.2014.58091.

19. United States Food \& Drug Administration. XTANDI® (enzalutamide). HIGHLIGHTS OF PRESCRIBING INFORMATION.

https://www.accessdata.fda.gov/drugsatfda_docs/label/2018/203415s014lbl.pdf. Published 2018. Accessed April 6, 2020.

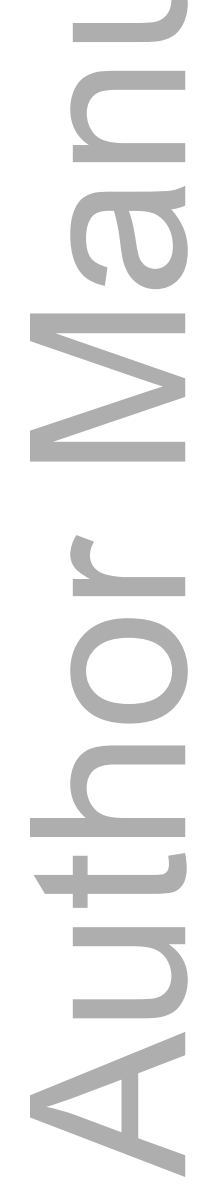

This article is protected by copyright. All rights reserved 


\section{University Library}

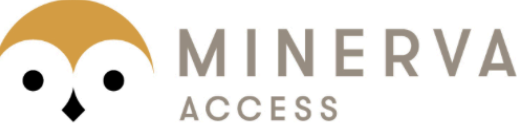

A gateway to Melbourne's research publications

Minerva Access is the Institutional Repository of The University of Melbourne

\section{Author/s:}

Goren, A;Vano-Galvan, S;Wambier, CG;McCoy, J;Gomez-Zubiaur, A;Moreno-Arrones, OM;Shapiro, J;Sinclair, RD;Gold, MH;Kovacevic, M;Mesinkovska, NA;Goldust, M;Washenik, $\mathrm{K}$

Title:

A preliminary observation: Male pattern hair loss among hospitalized COVID-19 patients in Spain - A potential clue to the role of androgens in COVID-19 severity

\section{Date:}

2020-04-23

\section{Citation:}

Goren, A., Vano-Galvan, S., Wambier, C. G., McCoy, J., Gomez-Zubiaur, A., MorenoArrones, O. M., Shapiro, J., Sinclair, R. D., Gold, M. H., Kovacevic, M., Mesinkovska, N. A., Goldust, M. \& Washenik, K. (2020). A preliminary observation: Male pattern hair loss among hospitalized COVID-19 patients in Spain - A potential clue to the role of androgens in COVID-19 severity. JOURNAL OF COSMETIC DERMATOLOGY, 19 (7), pp.1545-1547. https://doi.org/10.1111/jocd.13443.

Persistent Link:

http://hdl.handle.net/11343/278562 